\title{
Narratives of Value in Richard Brome's Dispute with the Salisbury Court
}

\begin{abstract}
The bill and answer for the 1640 court of request proceedings constitute the extant evidence of the terms of two contracts between Richard Brome and the Salisbury Court, one signed in 1635 and the other drafted in 1638 but unsigned. Inferring from these documents key differences between the contracts, this essay argues that the first contract left crucial ambiguities about the value of Brome's labour, and the company attempted to resolve these ambiguities to its advantage through the second contract and the bill of complaint. This evidence suggests a primarily antagonistic relationship between Brome and the Salisbury Court from 1636.
\end{abstract}

In 1635, Richard Brome signed a contract obligating him to write plays for the house company of the Salisbury Court playhouse. In 1638, a second contract was drafted but not signed. Because neither contract survives, our knowledge of their terms comes from subsequent legal proceedings. On 12 February 1640 the playhouse manager, Richard Heton, and members of Queen Henrietta Maria's Men presented a bill of complaint to the master of the court of requests accusing Richard Brome of having failed in his contractual obligation to supply the company with plays, for which Heton claimed damages of 'ffiue hundred pounds att the leaste.' ${ }^{1}$ If anything, Brome's answer, dated 6 March 1640, presented his potential worth to the company as even greater. He claimed, for instance, that one of his plays, The Sparagus Garden, 'was wor[th] to them ... One thousand pounds and vpwards', but argued that, despite his profit to them, Heton's company had failed to properly remunerate him either under the terms of his original contract or under the terms of a second, unsigned, contract. ${ }^{2}$ The questions that the court of requests, as a court of equity, had to deal with were ones of value and fairness: What benefits had each party received from the other? Had one party treated the other unfairly? If so, what did one party owe the other? In this case,

Bradley D. Ryner (Bradley.Ryner@asu.edu) is an associate professor in the department of English at Arizona State University. 
these questions hinge on an underlying question that is also fundamental to stage historians interested in the profession of playwrighting in early English theatre: what was Richard Brome's labour worth?

In 1971, G.E. Bentley offered one answer. He calculated that the weekly salary specified in the first contract plus a conservatively estimated $£ 5$ benefit per new play would have meant that Brome could reasonably expect an annual income of more than $£ 54 .{ }^{3}$ Although $£ 54$ would have been a very comfortable annual income for a playwright, Bentley concludes that 'Evidently the company did not think the terms of this contract excessive, for in August 1638 a new agreement was made, according to which Brome was to be given a 33 percent increase.' ${ }^{4}$ Bentley conspicuously omits conditions of the second contract that would have reduced this ostensible pay increase, which will be examined in detail below, and his passive construction 'a new agreement was made' sidesteps the vexed status of the second contract, which Brome never signed. Instead, he offers an account in which both parties clearly understood the cash value of each contract and judged the agreements to be mutually beneficial. Such narratives replicate the homo economicus model of classical economics, which assumes that a person's participation in a transaction implies a rational assessment that doing so will serve one's best interests. This fundamental premise, now seriously challenged by prominent economists, can be appealing because of the tidy stories it allows us to tell - but it does so at the expense of the messiness of the lived world. ${ }^{5}$

Recently, several excellent examinations of Brome's relationship with the Salisbury Court company have illuminated key aspects of this messiness, revealing constrained choices and untested gambles made in the context of complex personal relationships. Matthew Steggle situates the dispute in the context of the competition between Heton and the Beestons, each of whom had an interest in guarding resources (including plays, playwrights, and actors) from the other. ${ }^{6}$ Martin Butler shows that neither Heton nor the Beestons had the autonomous agency implied by the term 'impresarios', that has been used customarily to describe them, since they were working reactively to fend off economic threats with necessary deference to figures such as the master of revels. ${ }^{7}$ Eleanor Collins demonstrates that, contrary to prevalent assumptions, there is little reason to believe that companies regularly secured house playwrights by contract and attributes the novel arrangement in part to a novice playhouse manager and a playwright facing economic need. ${ }^{8}$

Unlike Bentley, these scholars avoid positing a specific cash value of either contract, and they scrupulously outline the ostensible terms of each. Like Bentley, though, they ultimately present both Brome and Heton as agreeing to these 
terms - however grudgingly — in 1635 and 1638 alike. I seek to add to this scholarship by returning some messiness to our understanding of the terms of the contracts themselves, which were from the start sites of ambiguity and contestation, and by foregrounding the persuasive strategies at work in the legal documents that argued for specific interpretations of these terms.

Heton's bill of complaint and Brome's answer to it necessarily preempt and problematize any story we might tell about the value of the contracts to the respective parties. In Thomas Postlewait's useful terminology, historical documents 'construct' events, which historians' narratives 'reconstruct.'? In this case, the homology between the shaping work done by the historical documents themselves and the shaping work done by historians' accounts of them is even more marked because the legal documents are already, explicitly reconstructions of the missing contracts, aimed not necessarily at detailing their original terms but at maximizing the court's sense of one party's obligation to the other. In what follows, I begin with what we can infer about the two contracts from the uncontested, or minimally contested, points in the bill and answer. I argue that the first contract left crucial ambiguities about the value of Brome's labour and that the second contract should be understood as an attempt to resolve these ambiguities to Heton's advantage, making it unlikely that Brome ever intended to sign it. I then examine the rhetorical aims of the surviving bill and answer. The bill, I argue, constituted a final attempt to force Brome to accept the terms of the second contract, while the answer sought to convince the court that only the first contract was potentially binding and that its terms had been either negated or substantially satisfied.

\section{From an Ambiguous Contract (1635) to an Unworkable One (1638)}

Given the obviously biased nature of the court of requests documents as well as their historical distance from the original contracts, any claim they make must be treated with a degree of scepticism. Nonetheless, the basic history of events that we can glean from the least contested parts of the documents is as follows. Both the bill and the answer concur that in July of 1635 Brome signed a contract, the letter of which stipulated that he would produce three plays per year for a term of three years, for which he would be paid 15 s per week. ${ }^{10}$ The overall spirit and limiting conditions of this contract were the subject of dispute. Less than a year later, in May 1636, plague forced the playhouse to close, and Heton ceased paying Brome his weekly salary. Heton's bill claims that cessation of payment 'in such Cases is vsual', but, as Brome's answer was careful to note, Heton did not claim 
the authority to do so from the original contract, which contained 'noe excepcon' indicating that Brome 'should not bee paied in case of such restraint' from playing. ${ }^{11}$ During the plague closure, Brome shopped a play to Christopher Beeston at the Cockpit, before uneasily reconciling with Heton, who agreed to buy the play instead. But this reconciliation broke down, and Brome again turned to Beeston before the master of the revels, Henry Herbert, intervened to arbitrate an agreement that would salvage the first contract. ${ }^{12}$ In August 1638, Heton drafted the second contract, which Brome did not sign. Heton's bill claims that Brome verbally agreed to it ('vowed and promised the pformance thereof; And willed that the same might be reduced into writeinge to that ende and purpose'). ${ }^{13}$ In his answer, Brome claims to have intended in good faith to sign until Heton's company 'Cavelled at' and 'discharged' him, leaving him 'at liberite.' ${ }^{14}$ Taken at face value, these claims suggest that, in 1638, both parties initially saw in the second contract the possibility of making a fresh start, the chance to renegotiate mutually beneficial terms that would allow them to take up the stable, long-term arrangement they had sought in 1635 . The terms of the second contract so far as one can recover them, however, should invite scepticism that either party could have seen it as a tenable framework for a continued relationship. Instead, the second contract amplifies the unworkable elements of the first.

The first contract, the terms of which were so ambiguous as to have required arbitration by the master of the revels, was evidently an unsatisfactory legal document in several ways. The most obvious defect of the original contract was its failure to make clear whether the 15 s per week salary was to be paid year round or only when the company was able to perform. Moreover, Heton's account of the arbitration and his larger legal strategy also suggest a further failing: the first contract seems not to have specified what penalties either party would incur for failing to fulfill its terms. When Roland Broughton (the closest analogous example) signed a contract with Lawrence and John Dutton and Thomas Goffe in 1572, he also signed at least two 'obligations' for $£ 20$ that he would have to pay if he failed to deliver the requisite number of plays, but that obligation would be forgiven if he did. ${ }^{15}$ No similar obligation seems to have been required of Brome. If Brome had been subject to a specific financial penalty under the first contract, the absence of any mention of it in the court of requests bill would indicate surprising carelessness on Heton's part (and downright negligence on the part of his lawyer) in missing the opportunity to point up the least disputable instance of a clearly defined obligation. Even if Heton would have preferred to receive plays rather than money, which Brome could not have afforded at any rate, a clear-cut financial penalty would have given Heton leverage to compel Brome to deliver the 
plays in return for forgiving or reducing the penalty. Instead, Heton's and Brome's accounts of the first contract figure Brome's obligation exclusively in number of plays owed. The problem with such a formulation - as must have been painfully clear by 1640 - is that there is no obvious equivalent value of a play. If Brome failed to deliver three plays per year, how much less should he be paid? The question becomes additionally difficult to answer if one accepts Heton's interpretation that Brome was not to be paid yearround but only when playing was permitted, making Brome's annual income variable and, thereby, ruling out figuring the value of each play simply as one third of a fixed total salary. How then, was the value of a play to be figured and what, at minimum, could Brome expect to receive for writing one?

The 1638 contract would have settled these questions to Heton's advantage. It specified monetary penalties for failing to deliver the agreed upon number of new plays, and - more importantly - affirmed that the conclusion of the first contract had left Brome owing the company additional plays, the delivery of which would be structured by the second contract. Under the new contract, Brome was to be paid 20s per week for delivering three plays per year for seven years while additionally delivering plays owed from the first contract. The adjustment from $15 \mathrm{~s}$ per week to $20 \mathrm{~s}$, though, was far from the simple ' 33 percent increase' in pay Bentley presents it as. If Brome did not deliver three plays per year (in addition to those owed from the first contract), 'halfe his paye or Salarye' would be withheld 'vntill hee had broughte in such playes as hee should bee behinde and in Arrere with them'. ${ }^{16}$ Thus, rather than being forced in the future to demand undelivered plays that Brome was unlikely to produce, Heton could simply cut Brome's pay in half if he fell behind. Moreover, the contract all but ensured that Brome would fall behind by specifying that he was to devote his efforts initially to delivering two of the four plays the company claimed they were still owed. ${ }^{17}$ For each of these two plays, Brome was to receive 50s; however, this $100 \mathrm{~s}(£ 5)$ was to count as the $£ 5$ that had been promised but never paid to Brome under Henry Herbert's arbitration of the first contract. While these specifications eliminated ambiguity by indexing the production of plays to monetary rewards and penalties, they did so in ways that overtly favoured the company. To receive the $£ 5$ he was owed, Brome had to deliver two of the four plays that he was 'in arrears' in time to be performed during Michaelmas term. If he delivered the third play within three years (for which it seems he would receive another 50 s, though the document is not clear here ${ }^{18}$ ), they would forgive the fourth play. Forgiving the fourth play might reflect Heton's desire to simply write it off rather than commit himself to paying an additional 50s for it, or it might reflect Heton's concession to Brome's 
claim that he did not owe a fourth play. In any event, the contract's provisions meant that by the end of three years the undelivered plays from the first contract would have been dealt with one way or another. Unless Brome had managed in the first year to deliver the two plays 'in arrears' and three new ones, his salary would drop to 10s per week. Given that Brome's customary rate of production seems to have been two plays per year, there would have been no reason to expect that he would have been able to make up any deficit from the first year, especially if the company planned to count one of the plays he subsequently delivered as the third play owed under the original contract, rather than counting it toward his annual quota of three new plays.

The economic consequences would have been severe for Brome, who maintained that he never thought himself capable of writing three full plays per year. Instead, he claimed, he and Heton had an understanding that the first contract's reference to 'three plays' was only meant to designate his full time labour, ensuring that he would 'dedi[cate] all his labour and playes totally vnto theire sole proffitts'. ${ }^{19}$ The pay scheme of the first contract might lend credence to Brome's claim. A salary of $15 \mathrm{~s}$ per week would have amounted to $£ 39$ per year. On the market, a new play could be expected to fetch around $£ 20$, so Brome could have expected to earn around $£ 40$ annually selling two plays per year on the market. ${ }^{20}$ Perhaps Heton and Brome based Brome’s salary on $£ 39$ per year as a low estimate of Brome's customary annual income that divided easily into weekly payments in whole shillings. Whereas delivering three plays for the price of two makes no sense, agreeing to work full time delivering around two plays per year in addition to miscellaneous writing (prologues, epilogues, revisions, etc.) in exchange for a stable weekly income does.

The pay scheme of the second contract, however, makes it impossible to interpret 'three plays' as anything but three full plays. Calculating the value of a new play under the second contract is a messy affair, but - however it is figured the math was unlikely to work in Brome's favour. If he delivered the plays 'in arrears' and three new ones, he would make $£ 52$ per year, or $£ 17$ 6s $8 \mathrm{~d}$ for each new one. If he delivered fewer than three plays, his salary would be cut to $£ 26$ per year - slightly more than he might have expected to make from selling one play on the market - regardless of whether he wrote one or two plays. This salary would additionally be cut in any circumstances that closed the playhouse as the second contract explicitly stated that Brome's salary was only to be paid at times that the company was able to play 'without restraint'. ${ }^{21}$ If the first contract had been an attempt to give stability both to the Salisbury Court company, by securing Brome's full labour, and to Brome, by guaranteeing him his customary 
income, the second contract was an attempt on the part of the Salisbury Court to exact as much labour from Brome as they could, at the lowest cost.

The new contract was additionally slanted in favor of the Salisbury Court in more subtle ways. The provision that Brome's salary should only be paid when the company could play 'without restraint' was part of a larger strategy that made the company's performance of a play, rather than Brome's authoring of it, sufficient to fulfilling the contract. If the company could not perform what Brome wrote, it was effectively not a play for the purposes of the contract. Even the deadline for delivering the first two plays 'in arrears' was figured from the perspective of performance. Brome was required to deliver the plays early enough in Michaelmas term for them to be 'studdied to bee presented vnto publique veiwe vppon the stage' before the end of the term. ${ }^{22}$ In other words, Brome was obligated to meet a deadline that was partly out of his hands, depending as it did on how quickly the company could work the plays into their repertory and whether the playhouse was open for public performances. Moreover, the company evidently felt no obligation to accept the plays Brome delivered. He complained that he delivered two plays (one in Hillary term 1638 and one before Easter term 1639) that were not only rejected by the company but ridiculed with 'scornefull and reproachfull speeches concerning this def.' ${ }^{2}{ }^{23}$ There is no way to tell if the company had legitimate concerns about the quality or performability of the plays or whether their rejection was, as Brome maintained, an excuse to 'stopp all weekly payments' and 'wearie [Brome] from and out of theire ymployment', forcing him to sell the plays to Beeston instead. ${ }^{24}$ The company may have been preparing for the lawsuit by putting pressure on Brome to break with them. Alternatively, they may have felt empowered by the yet-unsigned contract to accept plays only when they were in immediate need of them, allowing them to cut Brome's wages and prevent him from making headway on meeting his full contractual obligation.

Signing the 1638 contract would have been disastrous for Brome. Giving a pretense of considering a contract that he never meant to sign might have afforded him the chance to get more of the money he believed he was owed from Heton. An even more important consideration, though, might have been the plays that the contract would have allowed Brome to offer the company in exchange for his continued salary. The more plays he delivered, the less persuasive would be Heton's claim he was owed plays 'in arrears' from the first contract. Perhaps Brome understood his actions as merely delaying the company's legal action, and their decision to bring the case to the court of requests marked their recognition that they had failed at forcing Brome to accede to their preferred resolution of the dispute still lingering from the first contract. 
Looked at in this way, we can recognize a functional similarity between the proposed second contract and Heton's bill of complaint as legal documents. Both were narratives of value, attempts to establish unambiguous metrics for figuring the price of Brome's labour and to apply these metrics to the plays owed from the first contract as well as to subsequent plays Brome would deliver. The key difference between the two documents is that the contract depended on Brome's consent. Had Brome signed it, Heton would have had recourse to one of the common law benches to enforce it. Lacking the contract, he was left with the far riskier proposition of filing a bill in a court of equity in the hopes of convincing the court of the fairness of holding Brome accountable for undelivered plays.

\section{The Rhetorical Strategies of the 1640 Bill and Answer}

As Lamar M. Hill has shown, bills filed in the court of requests were rhetorically complex documents that draw on 'multiple discourses'. ${ }^{25}$ Lawyers produced the bill and answer in private consultation with the parties they represented. For the original bill, 'the story was told to a lawyer, then a discussion of the case between lawyer and plaintiff might follow, and finally the story was presented in a fashion that would both make its point more effectively and conform to legal protocol'. ${ }^{26}$ P. Harlowe, the lawyer whose signature appears on the bill, crafted it to place most of the emphasis on the terms of the second contract, even though - or precisely because - Brome had never signed it.

As a court of equity, like the chancery court, the court of requests was empowered to mitigate common law in the interests of fairness. It was established in the fifteenth century to deal with 'bills, requests and supplications of poor persons', but by the early sixteenth century had come to function as a lower-cost alternative to chancery used by a variety of people. ${ }^{27}$ To bring a case, one had to 'claim that they were too poor to sue elsewhere, that they were members of the royal household or engaged in crown business, or that they were unable to gain justice at common law, due to a lack of necessary proofs or other evidence, the power and influence of their opponents, or their inability to afford the costs of litigation'. ${ }^{28}$ The bill identifies using the court of request as necessary because Heton was not in physical possession of either of the contracts, which, the bill claims, were 'casually lost \& mislayed or are Come to the hands of the said Brome'. ${ }^{29}$ The bill asked, therefore, that Brome be summoned to 'fully sett foorth and declare the truthe of the same first and later Agreem ${ }^{\mathrm{t} \text { ' }}$ under oath. ${ }^{30}$ In other words, Heton's ideal outcome would have been the production through Brome's testimony of a 
legally binding agreement replicating the unsigned second contract and its interpretation of the first contract.

To this end, the rhetorical work of the bill consists not only in setting out the terms Heton wished the court to enforce but also in convincing the court that by not adhering to these terms Brome had profited unfairly to the company's detriment. The bill thus begins its narrative of events by claiming that Brome sought out employment with the Salisbury Court, 'well knoweinge That it would bee very beneficiall for him. ${ }^{31}$ It then quickly sketches the terms of the first contract as described above and claims that the company faithfully paid Brome's salary prior to the closure of the playhouses due to plague. Despite maintaining that it was customary to suspend pay during plague, the bill claims that the company tried to settle the dispute by agreeing to pay Brome $£ 10$ and subsequently exceeded this agreement by making up all but $£ 5$ of Brome's promised salary at the end of his contract. The bill invites reading the company members as overly credulous or desperate, throwing good money after bad 'vppon the promises of the said Brome That hee would pforme all his said Coven ants. ${ }^{32}$ It presents Brome as disingenuous and greedy, 'haveinge gotten soe much Money of $\mathrm{yo}^{\mathrm{r}}$ subiects' but still failing to deliver 'ffower playes' to Heton while endeavouring to 'sell and deliuer one of the playes' to the Beestons before being 'discouered'. 33

At this point, the bill recounts the terms of the second contract that it claims was 'Concluded and Agreed by and Betweene yo ${ }^{\mathrm{r}}$ subiects and the said Richard Brome' in August of $1638 .{ }^{34}$ The bill sets out the terms that the company wished the court to make legally binding and claimed that 'Broome Condiscended vowed and promised the pformance theerof; And willed that the same might bee reduced into writeinge to that ende and purpose.' ${ }^{35}$ It invites the court to interpret Brome's failure to go through with signing the second contract as part of a deception: 'Brome seemed very desirous to seale and Execute the same in due fforme of Lawe but from tyme to tyme delayed the same with Asservacón of his willingness to $p$ forme the said Agreement and to seale the said Artickles'. ${ }^{36}$ Though none too subtle, the indications that Brome was actively avoiding signing the contract ('from tyme to tyme delayed the same') receive less emphasis than his verbal promises to do so ('Condiscended vowed and promised,' 'with Asservacôn of his willingness'), allowing the court to imagine Brome's deceitfulness without fully undercutting the plausibility that the company believed itself to be in a goodfaith agreement with Brome. The bill claims that the company continued payments of his salary under the terms of the new contract. Nonetheless, the bill contends, Brome was lured away 'throughe the pswasions and inticement of the said $\mathrm{W}^{\mathrm{m}}$ Beeston', who promised 'to give him more salarye then $\mathrm{yo}^{\mathrm{r}}$ subiects by 
the Agreem ${ }^{\mathrm{t}}$ aforesaid'. ${ }^{37}$ The bill presents the court with a duplicitous playwright robbing the too trusting Heton and Queen Henrietta Maria's Men of their just 'Benefitte and proffitte' in a greedy attempt to improve his salary.

Lamar Hill has argued that answers to bills of complaint generally consist of multiple overlapping discourses, but necessarily feature a 'discourse with authority', directed to the masters of the court, that 'established a countervailing statement of legal sufficiency that obviated the need for equity and frequently demonstrated that it was the defendant and not the plaintiff who was being treated unjustly'. ${ }^{38}$ The answer's alternative account of the physical absence of the contracts is a significant part of this discourse with authority. Whereas the bill insists - with suspicious vagueness — that the contracts were 'casually lost $\&$ mislayed or are Come to the hands of the said Brome', the answer claims that the first contract was 'delivered vpp vnto this defend. ${ }^{t}$ to bee Cancelled' when the company refused to pay Brome during the plague closure. ${ }^{39}$ The answer's presentation of the second contract leaves ambiguous whether it was ever even drawn up at all: 'there was an other agreement made between the Company or some of them and the def. ${ }^{t}$ for the Composing of Playes for the rate of twenty shillings weekly, $\mathrm{w}^{\mathrm{ch}}$ agreement was intended to bee reduced into writing' but Brome's ill treatment by the company meant that 'theire was no further proceedings therein so as each partie was left to himselfe' ${ }^{40}$ Because the basis for bringing the case before the court of requests was Heton's claim to be missing the legal documents that would have allowed him to receive satisfaction in a court of common law, the court might have quickly settled the matter if they gave credence to the claim that the first contract was cancelled and the second abandoned by both parties before it was finalized.

Challenging the notion that Brome was legally bound by any agreement with Heton and Queen Henrietta's Maria's Men was the bedrock strategy of the answer, but most of the answer is devoted to presenting Brome as the one treated unjustly by the terms of the agreements, in case the court decided to adjudicate either agreement. Whereas the bill had presented Brome as the party seeking profit, the answer reversed the characterization - right down to claiming that it was not Brome who approached the Salisbury Court management, as the bill alleged, but the company who approached Brome with 'specious pretences and promises of reward and bountifull retribucon and love'. ${ }^{41}$ The bill claims that Brome's plays made the fledgling company 'very fortunate and succesfull' with plays like The Sparagas Garden bringing in 'One thousand pounds and vpwards'. ${ }^{42}$ The answer presents Brome as bringing 'the said Company into theire first and cheefest estimacon accompanyed with very great proffitts and gaynes' while they refused 
to pay him regularly, not only suspending his salary during the plague closure but also paying the $£ 10$ agreed upon to settle their dispute about the play he offered Beeston during the plague closure in 'severall small sumes and pettie driblings payments which did small pleasure vnto this def. ${ }^{\text {' }}$ and finally ending up $£ 1111 \mathrm{~s}$ $6 \mathrm{~d}$ in his debt by the end of the first contract. ${ }^{43}$

Heton and the company are presented as callously belligerent, either for disingenuous, self-interested reasons or for vindictiveness. The answer claims that the company 'intend[ed] Covenously or fraudulently to decieve and defraude' Brome through behaviour that not only went 'expresly against theire Argeement and Articles' of the first contract but also against 'all equitie and good conscience' crucial terms of a court of equity. ${ }^{44}$ It claims that Brome's objections to this treatment prompted them to cancel the original contract on a pretense and 'to put [Brome] to his shifts in that hard sadd and dangerous tyme of the sickness boeth for himselfe and his famyly. 45 The answer claims, nonetheless, that Brome reluctantly overcame their 'badd and vncharitable vsage' and agreed 'to make further tryall of them' both because of 'theire earnest perswasion and promises of better vsage' and, more ominously, because of their 'threates of suites and troubles'. ${ }^{46}$ This claim strikes an important balance. Presenting Brome as partly won over by 'promises of better vsage' maintains a sense of Brome acting in good faith as he continued to work with the company, while the claim that Heton used legal proceedings themselves as a threat in 1637 lends support to an argument that the 1640 lawsuit should be dismissed as vexatious: 'they do now out of mallice and evill will only molest and vex this def. ${ }^{\mathrm{t}}$ with suites of Lawe intending thereby to Crush and Ruyne him. ${ }^{47}$

The two primary aims of the answer, then, appear to be to convince the court that any contract binding Brome to the Salisbury Court playhouse had either been cancelled or never finalized and that the complainants' assertions to the contrary were attempts to exploit or ruin him. A tertiary aim was to provide a calculation by which Brome had met any obligation that he might be found to have to the company. Whereas the bill of complaint had devoted most time to detailing the second contract, the terms of which Heton sought to enforce, the answer largely neglects the second contract beyond asserting that it was never formally agreed to and that Brome never received any payment under its terms. ${ }^{48} \mathrm{It}$ treats the first contract extensively, though, presumably because Brome's lawyer, Andrew Brown, perceived its previsions to be at the heart of any obligation Brome might be found to have to the company. I have already mentioned above the assertion that Brome's The Sparagus Garden made the company windfall profits undercutting the company's ability for seeking relief in a court of equity — and 
that Brome was assured that the spirit of the first contract did not obligate him to deliver a specific number of plays but to devote 'all his labour' to the task. Additionally, the answer offered a calculation by which Brome might be understood to have fulfilled the first contract's quota of three plays per year. Taking into account the plays delivered to the company under various conditions since signing the first contract, the answer calculates that 'hee is only behind with them twoe Playes' but that he has done other writing work for the company ('made divers scenes in ould revived playes for them and many prologues and Epilogues to such plays of theires, songs, and one Introduccon') that 'amounted to asmuch tyme and studdy as twoe ordynarie playes might take vpp in writing. ${ }^{49}$ Thus, even if the court found that Brome had been legally bound to deliver three plays per year, they might have been convinced by this logic that Brome had already delivered to the company the equivalent value.

Presumably, one or more of the answer's strategies was effective. Although we lack any other documents from the proceedings, the prevailing consensus is most likely correct: Brome's subsequent work for Beeston and freedom to pursue publication of his plays indicate that the court sided with him and freed him for any obligation to the Salisbury Court playhouse. Nonetheless, much of our engagement with the contracts must remain speculative. The bill and its answer both aim to craft the historical narrative toward their particular ends. For details of the 1638 contract, we must rely primarily on Heton's bill, structured to convince the court of requests to impose specific future obligations on Brome. For details of the 1635 contract, we must rely primarily on Brome's answer, structured to convince the court of requests that Brome was in no way obligated by its terms. Any narrative that we can tell about how these contracts were initially understood is necessarily framed by the ways in which the value of each was strategically narrated in 1640 by parties who, there is good reason to believe, had been in a primarily antagonistic relationship dating back at least to the 1636 plague closure that precipitated their first documented dispute over the terms of the initial contract. 


\section{Notes}

An earlier version of this essay benefited greatly from feedback by Bill Ingram, Chris Matusiak, Kara Northway, and John Astington in a Shakespeare Association of America seminar on 'Kinds of Capital in the Early Theatre' led by Astington and Northway in 2016. I am also grateful to Eleanor Collins for commenting on a subsequent version and to the two anonymous readers who greatly helped to tighten the argument.

1 Throughout I quote the transcription by Ann Haaker, 'The Plague, the Theater, and the Poet', Renaissance Drama 1 (1968), 300, http://dx.doi.org/10.1086/rd.1.41917417. Before Haaker's rediscovery of the legal documents, they were known to C.W. Wallace, who referred to them in 'Shakespeare and the Blackfriars', The Century Magazine 80 (1910), 751, but did not identify their location in the Public Records Office. Wallace shared additional details reported in Clarence Andrews, Richard Brome: A Study of His Life and Works (New York, 1913), 14-15. The relevant portions of the above two works are excerpted in G.E. Bentley, The Jacobean and Caroline Stage, 7 vols (Oxford, 1968), 3.52-4. For historiography following Haaker's rediscovery, see: Gerald Eades Bentley, The Profession of Dramatist in Shakespeare's Time 1590-1642 (New Jersey, 1971), 107; Catherine M. Shaw, Richard Brome (Boston, 1980), 26-8; Andrew Gurr, The Shakespearean Playing Companies (Oxford, 1996), 430-3, http:// doi.org/10.1093/acprof:oso/9780198129776.001.0001; Glynne Wickham, Herbert Berry, and William Ingram, eds, The Professional Theater, 1530-1660 (Cambridge, 2000), 649-66; Matthew Steggle, Richard Brome: Place and Politics on the Caroline Stage (Manchester, 2004), 105-9 and 118-3; Martin Butler, 'Exeunt Fighting: Poets, Players, and Impresarios at the Caroline Hall Theaters' in Localizing Caroline Drama Politics and Economics of the Early Modern English Stage, ed. Adam Zucker and Alan B. Farmer (London, 2006), 97-128, http://dx.doi.org/10.1057/9780230601611 5; Eleanor Collins, 'Richard Brome's Contract and the Relationship of Dramatist to Company in the Early Modern Period', Early Theatre 10 (2007), 116-28, http:// dx.doi.org/10.12745/et.10.2.757, and Eleanor Clare Collins, 'Richard Brome and the Salisbury Court Contract' Richard Brome Online, 15 July 2019, https://www.dhi. ac.uk/brome/viewEssay.jsp?file=EC SALISBURY.

2 Haaker, 'The Plague, the Theater, and the Poet', 101.

3 Bentley, The Profession of Dramatist in Shakespeare's Time, 107.

4 Ibid.

5 For critiques of the rational model of homo economicus by behavioural economists, see Richard H. Thaler, Quasi Rational Economics (New York, 1991); Dan Ariely, 
Predictably Irrational (New York, 2008); and David Kahneman, Thinking Fast and Slow (New York, 2011); William Ingram, The Business of Playing: The Beginnings of the Adult Professional Theater in Elizabethan London (Ithaca, 1992), esp. Chapter 2, elegantly highlights the tacit assumptions about economic activity that inform stage historical narratives.

6 Steggle, Richard Brome, 105-9, 118-23.

7 Butler, 'Exeunt Fighting', 97-128.

8 Collins, 'Richard Brome's Contract', 116-28; Collins, 'Richard Brome and the Salisbury Court Contract'.

9 Thomas Postlewait, The Cambridge Introduction to Theatre Historiography (Cambridge, 2009), 29.

10 Haaker, 'The Plague, the Theater, and the Poet', 297, 301-2.

11 Ibid, 297, 303.

12 On the uncertainty of the timeline of these events, see Steggle, Richard Brome, 105-6.

13 Haaker, 'The Plague, the Theater, and the Poet', 299.

14 Ibid, 305.

15 Mark R. Benbow, 'Dutton and Goffe versus Broughton: A Disputed Contract for Plays in the 1570s', Records of Early English Drama Newsletter 6.2 (1981), 4.

16 Haaker, 'The Plague, the Theater, and the Poet', 298.

17 Ibid.

18 Ibid. The complaint specifies that Brome 'should bringe the third playe of the said ffower playes behinde in manner as aforesaid'. The phrase 'in manner as aforesaid' may have been meant to indicate that he would be paid the same for it as the other plays, but the meaning is not at all clear.

19 Ibid, 302. Lamar M. Hill, “"Extreame Detriment”: Failed Credit and the Narration of Indebtedness in the Jacobean Court of Requests', in Law and Authority in Early Modern England: Essays Presented to Thomas Garden Barnes, ed. Buchanan Sharp and Mark Charles Fissel (Newark, DE, 2007), 136-56. Hill argues that, at times, documents of equity proceedings 'allows us to "hear" the approximate voices of the participants', 139. Given Brome's professional alacrity with puns, perhaps we hear his voice in the answer's assertion that Brome fully intended 'to dedi[cate] all his labour and playes totally vnto theire sole proffitts'. The pun on 'playes' as pleasurable pastimes in the customary opposition between work and play heightens the sense of exploitation by suggesting that writing for the company consumes both work time and leisure time. Compare the puns on 'works' and 'plays' occasioned by Ben Jonson's 1616 publications of this plays as Works noted in C.H. Herford, Percy Simpson, and Evelyn Simpson, eds, Ben Jonson, 11 vols (Oxford, 1925), 9.13. 
20 Evidence of the market price of a new script is scant; however, in 1613, Philip Henslowe agreed to pay Robert Daborne $£ 20$ for Machiavel and the Devil. W.W. Greg, ed., Henslowe Papers: Being Documents Supplementary to Henslowe's Diary (London, 1907), 67-8.

21 Haaker, 'The Plague, the Theater, and the Poet', 299.

22 Ibid, 298.

23 Ibid, 304.

24 Ibid.

25 Hill, “"Extreame Detriment”', 140. Collins rightly draws attention to the rhetorical nature of Heton's complaint and Brome's answer as 'highly charged, argumentative exercises in the legal discourse of the time', each of which 'works towards an explicit agenda of compensation: either in terms of money, or in undelivered plays'. However, her characterization of them as 'memorial accounts ... delivered in court-hearings spread across weeks, and then transcribed' downplays how highly crafted they were. Collins, 'Richard Brome', para. 3.

26 Hill, “"Extreame Detriment”, 140.

27 See J.H. Baker, An Introduction to English Legal History, $4^{\text {th }}$ edn (London, 2002), 120. For general information on the history and procedures of the court of requests, see also I.S. Sanders, ed., Select Cases in the Court of Requests, A.D. 1497-1569 (London, 1898), ix-xxii; L.M. Hill, ed., The Ancient State Authoritie and Proceedings of the Court of Requests by Sir Julius Caesar (Cambridge, 1975), xxvii-xxxviii; Tim Stretton, ed., Marital Litigation in the Court of Requests 1542-1642 (Cambridge, 2008), 7-15.

28 Stretton, Marital Litigation, 10.

29 Haaker, 'The Plague, the Theater, and the Poet', 300.

30 Ibid.

31 Ibid, 297.

32 Ibid, 298.

33 Ibid.

34 Ibid.

35 Ibid, 299.

36 Ibid.

37 Ibid.

38 Hill, “"Extreame Detriment”, 141.

39 Haaker, 'The Plague, the Theater, and the Poet', 300, 303.

40 Ibid, 305-6.

41 Ibid, 297, 301.

42 Ibid, 301. 
43 Ibid, 302, 304.

44 Ibid, 303.

45 Ibid.

46 Ibid.

47 Ibid, 305.

48 Ibid, 305-6.

49 Ibid, 305. 